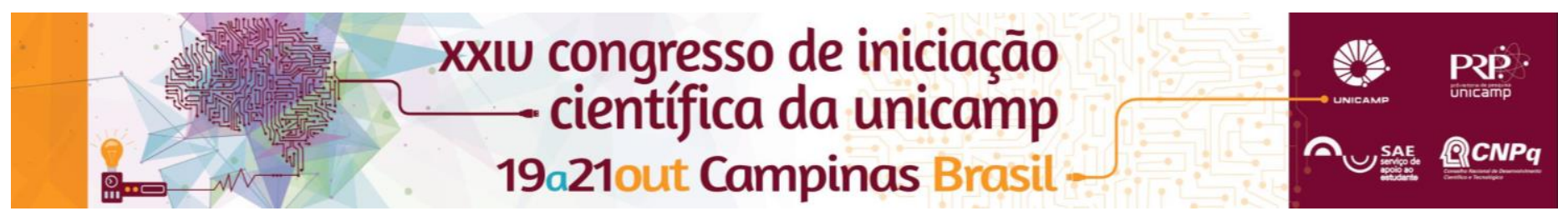

\title{
AVALIAÇÃO DOS GASES DE EFEITO ESTUFA NO PROCESSO DE DESNITRIFICAÇÃO EM REATORES ANAERÓBIOS
}

\author{
Bruno Celotti*, Taína M. Magalhães, Alexandre C. D. Batista, Adriano L. Tonetti
}

\begin{abstract}
Resumo
A remoção do nitrogênio de efluentes pode ser feita em reatores anaeróbios por meio da desnitrificação, a qual pode emitir gases considerados atuantes no efeito estufa. Sendo assim, utilizando-se um reator UASB e um de filtro anaeróbio alimentados com efluente sintético e concentração conhecida de nitrato, foi analisada a remoção de DQO, de nitrato e a composição do biogás gerado. A eficiência de remoção de DQO foi superior para o filtro anaeróbio, porém, quanto à remoção de nitrato, não houve diferença entre os reatores. Com relação ao biogás, não foi detectado óxido nitroso em nenhuma etapa, porém nas etapas com presença de nitrato no efluente a concentração de metano e gás carbônico foi menor do que na etapa sem presença de nitrato.
\end{abstract}

Palavras-chave:

Desnitrificação, Reatores Anaeróbios, Biogás

\begin{tabular}{cccc}
\hline Etapa & Bruto $(\mathrm{mg} / \mathrm{L})$ & $\mathrm{UASB}(\mathrm{mg} / \mathrm{L})$ & $\mathrm{FA}(\mathrm{mg} / \mathrm{L})$ \\
\hline 1 & $426,8 \pm 18,5$ & $102,6 \pm 25,2$ & $62,2 \pm 17,7$ \\
2 & $421,7 \pm 11,8$ & $95,6 \pm 18,3$ & $55,6 \pm 20,1$ \\
3 & $415,6 \pm 15,9$ & $103,0 \pm 16,8$ & $59,2 \pm 15,7$
\end{tabular}

Introdução

O tratamento de esgoto com o uso de sistemas anaeróbios requer a remoção da matéria orgânica e também de nutrientes, como o nitrogênio, o qual pode estar presente de várias formas nestes efluentes e pode ocasionar doenças como a meta-hemoglobina caso seja consumido em excesso na forma de nitrato.

Porém o processo biológico responsável por remover o nitrato, a desnitrificação, produz gases como o óxido nitroso, considerado gás de efeito estufa. Esse processo ocorre segundo a Equação 1:

$$
\mathrm{NO}_{3} \rightarrow \mathrm{NO}_{2} \rightarrow \mathrm{NO} \rightarrow \mathrm{N}_{2} \mathrm{O} \rightarrow \mathrm{N}_{2}
$$

Gases como o metano e o gás carbônico também são formados devido à decomposição da matéria orgânica, sendo assim necessário monitorar a produção dos gases efeito estufa na desnitrificação e na metanogênese.

Portanto, neste projeto, os objetivos principais são a caracterização do biogás formado e análise das características do efluente produzido, comparando-as entre ambos os reatores.

\section{Resultados e Discussão}

Para os experimentos foi utilizado efluente sintético para ambos os reatores, variando-se apenas as concentrações de $\mathrm{N}^{-\mathrm{NO}_{3}}{ }^{-}$em cada etapa: 0,0mg/L (Etapa 1), 25,0 mg/L (Etapa 2) e 50,0 mg/L (Etapa 3).

Os reatores foram construídos com tubos de PVC onde o efluente é bombeado pela parte de baixo do reator e as amostras de gases e do efluente final são coletadas no topo. Os parâmetros do efluente analisado foram as concentrações de $\mathrm{DQO}$ e $\mathrm{N}-\mathrm{NO}_{3}{ }^{-}$. O biogás coletado foi analisado via cromatografia gasosa em termos de $\mathrm{CH}_{4}$, $\mathrm{CO}_{2}$ e $\mathrm{N}_{2} \mathrm{O}$.

A concentração de nitrato manteve-se próxima à adicionada no efluente bruto e nas saídas, abaixo da detecção, indicando a remoção praticamente total do nitrato presente no efluente bruto.
Tabela 1. Resultados de concentração de DQO Observa-se pela Tabela 1 que a remoção de DQO não teve uma relação com a concentração de nitrato no efluente, porém houve a maior remoção desta no reator de filtro anaeróbio (em torno de $10 \%$ a mais).

Quanto ao biogás não foi detectado $\mathrm{N}_{2} \mathrm{O}$ em nenhuma etapa. Não houve diferença na composição entre os reatores, porém, o $\mathrm{CH}_{4}$ e $\mathrm{CO}_{2}$ foram encontrados em maior concentração na Etapa 1, como apresentado na Figura 1.

Figura 1. Composição do biogás em $\mathrm{CH}_{4}$ e $\mathrm{CO}_{2}$

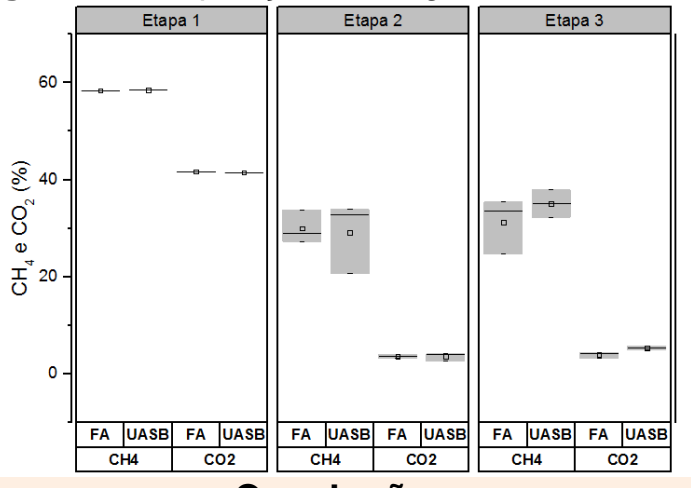

\section{Conclusões}

Pode-se concluir, portanto, que a concentração de nitrato no efluente não influencia na remoção de matéria orgânica em nenhum dos reatores, mas o reator de filtro anaeróbio possui uma maior eficiência nesta remoção quando comparado ao UASB.

Para a remoção de nitrato, não houve diferença entre os reatores para as concentrações iniciais de nitrato utilizadas, visto que em todos os casos a concentração de nitrato na saída encontrava-se abaixo da detecção.

O biogás formado nos dois reatores não obteve diferença significativa, porém, houve menor geração de $\mathrm{CO}_{2}$ e $\mathrm{CH}_{4}$ quando não havia nitrato no efluente.

\section{Agradecimentos}

Ao CNPq por ter fornecido a bolsa de iniciação científica, ao professor Dr. Adriano L. Tonetti e à mestranda Taína M. Magalhães pelo auxílio com a pesquisa e a todos os demais funcionários e amigos do LabSan. 